SOLINGER, Dorothy J. (ed.). 2018. Polarized Cities.

Portraits of the Rich and Poor in Urban China. Lanham, Boulder, New York, London: Rowman and Littlefield.

Éric Florence

\title{
OpenEdition
}

Journals

\section{Electronic version}

URL: https://journals.openedition.org/chinaperspectives/10007

DOI: 10.4000/chinaperspectives. 10007

ISSN: 1996-4617

Publisher

Centre d'étude français sur la Chine contemporaine

\section{Printed version}

Date of publication: 1 March 2020

Number of pages: $53-54$

ISSN: 2070-3449

\section{Electronic reference}

Éric Florence, "SOLINGER, Dorothy J. (ed.). 2018. Polarized Cities. Portraits of the Rich and Poor in Urban China. Lanham, Boulder, New York, London: Rowman and Littlefield.", China Perspectives [Online],

2020-1 | 2020, Online since 01 March 2020, connection on 02 July 2021. URL: http://

journals.openedition.org/chinaperspectives/10007; DOI: https://doi.org/10.4000/chinaperspectives. 10007

This text was automatically generated on 2 July 2021.

(c) All rights reserved 


\title{
SOLINGER, Dorothy J. (ed.). 2018. Polarized Cities. Portraits of the Rich and Poor in Urban China. Lanham, Boulder, New York, London: Rowman and Littlefield.
}

\author{
Éric Florence
}

1 From her 1999 benchmark book Contesting Citizenship in Urban China, States' Gains, Labor Losses (2009), to Socialism Vanquished, Socialism Challenged (2012), Dorothy Solinger has relentlessly investigated issues of urban poverty (from rural migrants to the urban destitute) and of the role of the state and the plannedeconomy era institutions in (re) producing socioeconomic polarisation.

2 Bringing together nine contributions, Polarized Cities sets out to understand how, along with three decades of extremely high rates of growth, socioeconomic changes have led to increasingly entrenched inequality and to the superrich and the most destitute living in quasi sealed-off "caste-like formations." How "this bifurcation" has been made possible

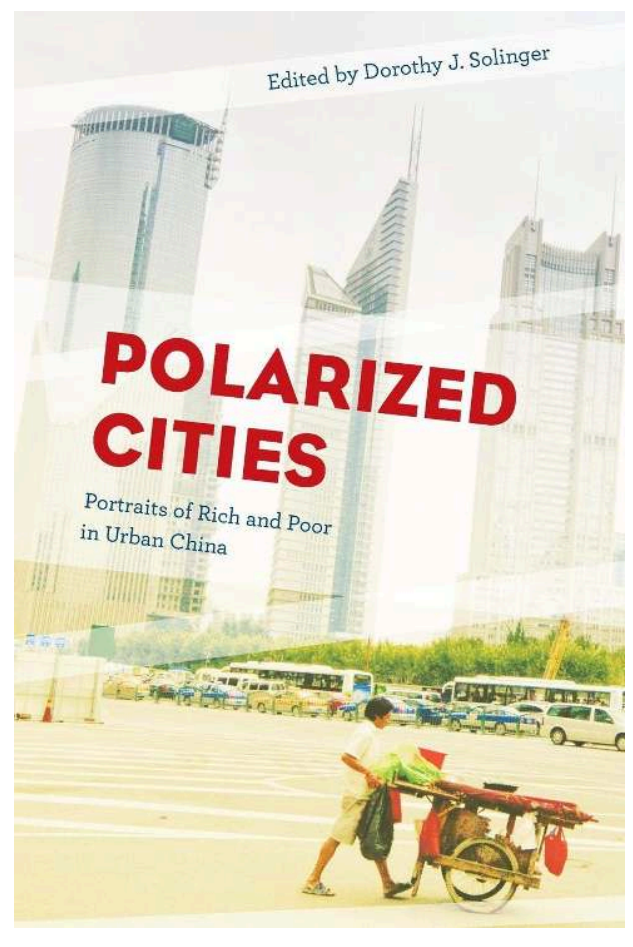
is the central question tackled by the contributors to this edited volume (p. 2). 
3 In her introductory chapter, Dorothy Solinger develops the main arguments providing coherence to the book. She puts forward three interrelated points. Firstly, she reviews both quantitative and qualitative scholarship assessing inequality in post-Mao China. A chief insight of this scholarship points to the combination of major political choices such as the privatisation of housing, the dismantling of state-owned enterprises, etc. with the enduring effects of socialist-era institutions, which together have aggravated socioeconomic polarisation and rendered escaping from destitution increasingly difficult for the urban poor. Secondly, Solinger points to the core role of the state in producing this inequality even if, as she notes, this may not have been intentional on the part of the Chinese state. Thirdly, she highlights a global pattern of blocked social mobility. These three themes are echoed in most of the chapters of Polarized Cities. Solinger also goes into some detail to define "agency" as being at once constrained but also enabled by structures of domination (p. 2). Wang Feng's piece is an excellent addition to Solinger's introduction in providing readers with a broad picture of the historical and political conditions of changes in inequality over the last four decades. Wang Feng documents why the Chinese government's attempts at reducing inequality constitute what he terms "an uphill battle" (p. 24). He focuses on two core facets of this battle. He firstly sheds light on how economic inequality has shifted from an "inequality in revenue" to a far more deeply-entrenched "inequality in wealth," which is now passed on from one generation to the other. Secondly, he documents declining educational and occupational mobility. He then assesses the attempts by the Chinese government at reducing inequality.

4 In the second part of the book, Zhang Li explores how the rich and the poor cope with problems of access to urban space and land, with air pollution and with psychological distress and emotional issues (p. 44). Solinger then explores how the Chinese state has been dealing with the urban poor through its "Minimum Livelihood Guarantee" (dibao 低保) from 1999 onward. She shows a relative change of priority from initially focusing chiefly on providing allocations to the urban poor, to tilting more towards the rural destitute from 2013 onward, when funding for the rural poor started to exceed transfers to the urban destitute. Comparing the dibao to poverty alleviation programs in other countries of Latin America, she finds that even when urban and rural funding of the dibao are added, the proportion of GDP devoted to poverty alleviation in China remains far below the average for Latin America (pp. 74-5).

5 In the next contribution, Mun Young Cho looks at Foxconn workers' engagement in affective and relational labour through participating in voluntary social work. Based on four years of ethnographic research at Foxconn in Shenzhen, Cho puts forward the notion of "ethical citizenship," which in the absence of social and political rights works through workers' "choices, desires and aspirations" (p. 88). She highlights that the engagement of the "passionate poor" in social work cannot help them out of the "castlike position" they are stuck in, and that these workers' "social suffering leads us to recognize the simultaneous occurrence of their structural exclusion in material production but their individual inclusion in social production" (p. 103).

6 Joshua Goldstein then provides a rich historical overview of the informal recycling sector in Beijing in post-Mao China. From the routine repression and law and order management of trash-collectors (1990s to 2003) to a "live-and-let-live" approach by municipal authorities (p. 119), Goldstein depicts the resilience of informal recyclers despite a sustained pattern of adverse policies by the municipal government. The fact, 
Goldstein argues, that this dense network of informal recyclers has been able to subsist until today is at once a testimony of the agency of these recyclers and of the mix of incapacity and unwillingness on the part of the municipal authorities to control and fully uproot the informal recycling market.

7 Part III starts with a historical view of the clubbing industry in Shanghai from the late 1980s' working-class culture dance halls, to the 1990s' karaoke and lounge bar culture, up to today's exclusive hyper-rich "king in his castle" model (p. 128). They show how the rather fluid and open spaces of karaoke and lounge bars of the 1990s that provided venues for mixing people of different classes, professional, and rural-urban backgrounds, gave way from 2005 onward to "safe space catering only to the young fuerdai (富二代)” (p. 139). In his chapter on corruption and class formation of China's new rich, Osburg describes a very similar closing-off process within urban elite circles among the second generation of the urban rich (fu'erdai). The last decade has seen, Osburg observes, the consolidation of what he terms "the established elites" or a "cast system at the very top," with access to this sealed circle ever more difficult for new members unless acquired by birth.

On the whole, the somewhat provocative argument of the formation of a cast-system at both ends of the social spectrum is rather solidly substantiated. The historical depth of several contributions (Solinger, Wang, Goldstein, Field and Farrer, Osburg) enables identifying the changes in patterns of inequality, wealth concentration, and class consolidation over the last three decades. In their respective chapters, Wang Feng, Dorothy Solinger, and David Goodman show that despite the major policies initiated by the government in social welfare, it is the most privileged who have benefited most from public redistribution in health, pension, and education. Wang Feng puts it rather trenchantly: "Economic and social inequalities have become systematic, structural and durable (...)" and "the state has played a direct role in generating inequalities between those who are close to the system and those who are not" (p. 37). Other chapters by Cho, Goldstein, and Field and Farrer indeed also concur in depicting an overall pattern of declining educational and occupational mobility, with family background turning into an ever-more crucial factor in determining socio-economic success. As a matter of fact, despite the massive expansion of access to higher education over the last three decades (more than a six-fold increase between 1998 and 2014), the rural-urban discrepancies in accessing college have increased, and for both rural kids and kids from poor urban families getting into college has become an ever-increasingly out-of-reach target, not to mention accessing elite colleges (p. 32).

9 Another major feature that comes up in the book is the deeply entrenched and highly resilient alliances between political and economic forces and the role of political elites in enabling and consolidating wealth accumulation and concentration since the start of the post-Mao era. Regarding these alliances, the extent of the anti-corruption campaign under Xi Jinping stands, Wang Feng notes, as an illustration of "the pervasiveness and the magnitude of the marriage between power and money" (p. 31).

10 As the book delivers a rather bleak picture of socioeconomic change in today's China, a major issue is left unaddressed, except slightly in Wang Feng's piece, which is the never-ending process of the formation and consolidation of state legitimation. This calls for future research on how various levels and agents of the Chinese Party-state deal with an increasingly polarised society. 


\section{BIBLIOGRAPHY}

SOLINGER, Dorothy J. 1999. Contesting Citizenship in Urban China. Peasant Migrants, the State and the Logic of the Market. Berkeley: University of California Press.

SOLINGER, Dorothy J. 2009. States' Gains, Labor's Losses. China, France and Mexico Choose Global Liaisons, 1980-2000. New York: Cornell University Press.

BENDELJ, Nina, and Dorothy J. SOLINGER (eds.). 2012. Socialism Vanquished, Socialism Challenged. Eastern Europe and China, 1989-2009. New York: Oxford University Press.

\section{AUTHOR}

\section{ÉRIC FLORENCE}

Éric Florence is Associate Professor at the University of Liege, Faculty of Philosophy and Humanities (East Asian Languages and Literature), Place du 20-Août, 74000 Liège, Belgium. eric.florence@uliege.be 